\title{
THE UNITED STATES' STRATEGIC INTERESTS: THE CENTRALITY OF EAST ASIA, THE IMPORTANCE OF THE PIVOT AND THE RISK OF DISTRACTION ${ }^{1}$
}

\author{
Balazs Szanto
}

\begin{abstract}
The article examines the strategic dilemma faced by the United States (U.S.) concerning the conflicting interests in the Middle East and East Asia. The article focuses on analysing U.S. policy towards East Asia within the context of Obama's Pivot to Asia and the possibility of militarized counter-terrorism in context of primarily the Islamic State. The article argues that East Asia represents immense strategic value for the U.S., while the Middle East is comparatively offers only limited strategic concerns. Thus the article concludes that the U.S. should devote its attention to East Asia, focusing on the successful execution of the pivot, while remaining restrained in its engagement with the Middle East. The methodology used is based on evaluating government policy along two main avenues: is the goal significant enough to be pursued, and is the policy adopted effective in achieving said goal? In the case of East Asia, both the goals are crucial to pursue and the method adopted, the pivot, is effective. In the case of the Middle East, the goals fail to demonstrate the same importance and the method employed demonstrates a highly ineffective approach.
\end{abstract}

Keywords: United States, China, security policy, pivot, terrorism

\section{INTRODUCTION}

What should be the object of security policy, especially when it comes to the application of military power? This is the question facing Washington. Is it to secure long-term strategic interests of the nation? Or is it to carry out the collective moral judgment of the nation, to confront forces that enrage the collective consciousness of the country? Kelly wrote an article for The Diplomat ${ }^{2}$ that seeks to 
explore this issue: should the United States (U.S.) devote its attention to East Asia through a continued focus on Obama's proposed Pivot to Asia, or should the U.S. engage in a broader military campaign against Islamic State of Iraq and Syria (ISIS) militants in Syria? Which is the rational course of action?

This article seeks to explore this issue in depth. The question is especially relevant today: On the one hand, recent years saw a significant increase in tension in East Asia as Beijing adopted a more assertive approach towards its neighbours. On the other hand, recent tragic events, such as the Sydney café siege and the Paris attacks, are once again increasing fears over terrorism, resulting in increasingly loud calls to engage ISIS directly through military force. The sheer barbarity of the group horrifies Western nations and provides a foundation for calls to the application of traditional security solutions to a non-traditional security problem. The goal of this article is to show, in agreement with Kelly, that, despite moral outrage, U.S. strategic interest lie in East Asia and that the U.S. should focus its attention on the execution of the pivot, rather than extensively getting involved once again in the Middle East.

As this article touches upon recent tragedies, it is important to state that the arguments below are in no way meant to downplay the severity of recent events. However, it is important, especially during troubled times when emotions run high, to formulate policy rationally and with a cool head, focusing on long term objectives over short term gratification. This article recognizes the moral evil presented by terrorism. However, this article will adhere to the principle outlined by Gray that "in the search for best practices in strategic affairs we can, and should, be able to disentangle moral judgments from strategic ones." ${ }^{3}$ The key objective of security policy is to protect a nation's interests and ensure its survival, and the two competing security objectives will be evaluated based on their ability to serve these objectives alone.

\section{MILITARY FORCE AND REGIONAL HEGEMONY}

Before discussing the two conflicting strategic directions, i.e. the Middle East and East Asia, it is crucial to identify some underlying assumptions about the international system which will serve as the 
basis for evaluating said policies. This article is written in the spirit of realism; offensive structural realism as defined by Mearsheimer to be precise. It is often seen contrary to the contemporary zeitgeist to be a realist. According to offensive realism the contemporary international system is defined by the interactions between rational, sovereign nation states. The system is anarchic because of the very sovereign nature of these states and thus survival is the highest interest of any state, as continued existence is a prerequisite to the pursuit of any other interests. How does this relate to military force, strategy and regional hegemony?

Due to the anarchic nature of the international system, i.e. as opposed to the organized nature of the domestic environment where the state acts as a protector of and arbiter between citizens, states are inherently insecure. In a state of existence lacking the organizing force of a higher power states have a legitimate reason to be continuously concerned about their existence, as well as their continued ability to pursue their interests within the international arena. Obviously states wish to escape this state of existence and achieve a state of security.

The core principle of offensive realism is that this can be achieved through the acquisition of military power: Sufficient military build-up enables a state to use force both defensively and offensively. Possessing a strong military protects the state from external aggression, i.e. if the state is attacked it has the means to defend itself. At the same time, a strong military is also useful if another state prevents the state from fulfilling a key interest as it can be used to rectify the situation in an offensive manner. In the end, military power underwrites all other aspects of state power. ${ }^{4}$ A state cannot wield economic power without military power enabling it: An economically powerful but militarily weak state would face a substantial risk of invasion, an aggression it would by design not be able to resist, at the hand of militarily powerful states who would divide up the spoil among themselves. Quoting Japan as an example to the contrary is a fallacy. Japan could afford to be militarily weak because of the continued protection of the United States, a military superpower. Similarly, political power is dependent on a state's ability to exercise force: A state can only force its will on others if it has the means to inflict punitive damage in case of non-compliance. Economic sanctions could be mentioned but they 
are dependent on the unreliable cooperation of other states, besides of the risk of one trying to exercise economic coercion without sufficient military security surely resulting in defeat.

The anarchic nature of the international system prompts security seeking behaviour, which in turn prompts the acquisition of power that states can leverage into security. Military might is the currency of power. ${ }^{5}$ Naturally states seek to achieve a surplus of power compared to their peers to feel secure. If one possesses less power than its neighbour, the chance of becoming a victim of said state is high. If a state possesses equal power to its neighbour, it also possesses equal chance of either becoming the victim or the victor in a confrontation. If a state possesses more power than its neighbour, the chance of becoming a victim is low, albeit the situation applies in reverse to the other states, creating the classical security dilemma. Each inch the chasm of power is increased between a state and its peers improves its security. The ultimate objective of security seeking behaviour is to become a regional hegemon, i.e. achieving a state when all significant military threats from one's home region have been eliminated, ensuring one's security. Such a state also frees a hegemon to project power globally.

Unipolar hegemony is preferable to any state. Being the only hegemon allows unprecedented security, as there is no other comparable military power that could pose a significant challenge. Major interests are protected. The emergence of a new hegemon alters this state, lowering the existing hegemon's security. The emergence of a new hegemon of equal military might means that the fulfilment of major interests are no longer self-evident, as there is a state with the necessary power to oppose them. To illustrate through a practical example, let's assume that there is a lesser power with substantial natural resources the hegemon desires. In a unipolar system, if the lesser power decides not to cooperate the hegemon can use its military might to coerce compliance, and there would be very little option to oppose it. In a bipolar system there are two alternative routes. On the one hand, it is possible that the rival hegemon also desires said resources. In this case the competition would be resolved through a military engagement between hegemons of equal strength, with less than ideal chance of success for either one of them, especially compared to a unipolar system. On the other hand, even if the other 
hegemon does not desires the same resources, it might oppose the acquisition of the territory simply to prevent its rival from acquiring more power, again resulting in a military confrontation between equal powers, if carried to its logical conclusion. The emergence of even more hegemons further reduces the security of the existing ones. Descending into a multipolar hegemony would create a complex web of opposing interests and balance of power considerations. This would further lower individual hegemons ability to pursue their interests successfully. Thus, hegemons have a vested interest in preventing other major powers from achieving regional hegemony of their own.

\section{KEY QUESTIONS IN EVALUATING GOVERNMENT POLICY}

When evaluating government policy, there are two crucial questions to ask: First, is the policy concerned with a significant enough issue to warrant attention, i.e. is the goal of the policy worth pursuing? Washington could certainly devise an excellent policy to tackle the problem of educational underachievement amongst underprivileged ukulele players of Scandinavian descent. It could commit resources and energy to identify and comprehensively address the various factors behind this made-up phenomenon. However, as this affects a statistically negligible portion of the population, the benefits of such a policy would be disproportionally low compared to the investment. As such, this would not be a worthy goal for the government to pursue.

Second, is the policy objective pursued effectively? Improving education to the overall population would be a worthy goal. However, the government could decide to achieve this through withdrawing funding from schools that face difficulty in passing standardized testing. Such a policy would create an environment where schools that have difficulty teaching would lose funding and would need to fire teachers, increase classroom numbers and so on so forth, further reducing the quality of education provided. This would not be an effective way of pursuing the objective of improving the general level of education because it would leave behind those who needed most the assistance of the policy in the first place. In the following the issue of East Asia and the Middle East will be assessed on this basis. Should the U.S. be involved in the first place? And if so, should it do in the manner proposed by current policy? 


\section{EAST ASIA AND THE PIVOT}

As mentioned above, the key issue facing Washington in East Asia is how to deal with the rise of China. This question directly relates to the problem of existing and emerging hegemons discussed in the abstract above. The U.S. is the sole regional hegemon in the current system, enjoying all the privileges of a unipolar hegemony, since the Soviet Union was vanquished at the end of the Cold War. The U.S. faces no significant threat in its home region - it is very unlikely that Canada, Mexico or Uruguay would try to invade it - and it is free to project power across the globe at unprecedented scale. The U.S. is the world's largest economy with a US\$16.8 trillion total GDP in 2013, 1.8 times higher than the second largest economy's. In effect the total economic might of the U.S. is only US\$1 trillion short of the combined economic might of the next three states on the list. ${ }^{6} \mathrm{An}$ even more significant disparity can be observed in military spending. In 2013, the U.S. had spent US $\$ 640$ billion on its military, almost 3.5 times the amount the next state on the list spent. The US spent the same amount on its military as the nine following states combined. ${ }^{7}$ This is a meaningful gap of power, elevating the US into a position without a peer. So why should the U.S. be worried about East Asia in general, and the rise of China in particular?

The U.S. should worry because on all of these lists China is the second one. China registered a total GDP of over US\$9 trillion in 2013 with a military budget of US $\$ 188$ billion. The Chinese GDP was almost two times higher than the number three on the list (Japan) ${ }^{8}$ and its defence spending was over two times higher than the nearest competitor's (Russia). ${ }^{9}$ In effect, China is the closest competitor to the United States at the moment, and the state with the highest chance of becoming the next hegemon. This is especially so as Chinese military spending increased on average 15 percent between 2010 and 2013 on a yearly basis, while U.S. defence spending decreased by 2.8 percent on average on year by year basis during the same period. ${ }^{10}$ At the same time, during the 2010-2014 period, the Chinese GDP grew at 7.7 percent annually, as opposed to the 1.9 percent growth of the U.S. ${ }^{11}$ These trends all point to a rapidly growing China and a stagnating U.S. The simple fact is that if any state has a reasonable chance of success of closing the gap with the U.S., it is China. The current balance of actual power continues to heavily favour the U.S.: 
the People's Liberation Army (PLA) is no match for the might of the U.S. military. However, Mearsheimer highlights the importance of latent power, i.e. the capacity to acquire further power. China has a large population and a large and growing economy supporting a large and growing military.

And China is beginning to exhibit the signs of a state seeking regional hegemony. It is highly concerned with its security and it increasingly identifies the presence of the U.S. in its home region as a key insecurity. It actively seeks to remove the U.S. threat by creating an extended naval buffer zone on the East and South China seas and by disrupting the U.S. led alliance system in the region. This attitude was crystalized by a senior PLA-N People's Liberation Army-Navy's (PLA-N) officer's gallant, albeit controversial, offer that China should take over the management of the western Pacific region from the U.S. China's growing tension with Japan, and increasingly visible desire to militarily oppose the island nation also points to its desire, not only to remove the external hegemon from the region, but to pacify any regional threat.

Thus, in East Asia the U.S. faces a major power following the rational path, outlined by the systemic forces affecting the international system, to escape its own insecurity by becoming a regional hegemon. And as discussed in the abstract above, the emergence of a new hegemon, and the creation of a bipolar system, would significantly impact U.S. security. How would Beijing's achievement of regional hegemony affect Washington? It would represent a return to the Cold War dynamic of the international system dominated by direct competition between two superpowers. Despite the ideological window dressing, the Cold War at its core was the competition between two hegemonic military powers for influence over the rest of the world, and to successfully carry out one's interest while preventing the other from doing so. There is no reason to assume that the dynamic emerging between the U.S. and China would be any different. The U.S. would need to compete with China for its interest from the significantly weakened position of equality. It would also need to adopt the pace of Chinese military development to prevent China from further altering the balance of power, a most certainly expensive competition, which would require Washington to reserve an ever-increasing portion of the national output for defence. Washington would also lose its current 
ability for coercion, as states unfriendly to U.S. interests could seek effective protection from China. To put it simply, the U.S. would lose the privilege enjoyed within the current unipolar system and would need to pursue its interests from a meaningfully more difficult situation. As this would affect any and all U.S. interests, the prevention of such a situation is most certainly a worthy goal for U.S. foreign policy.

The Obama administration's answer to the conundrum at hand is what became to be called the U.S.' 'pivot to Asia' or a strategic rebalance. As the rise of China presents a traditional security threat, i.e. the threat of war between nation states, the pivot mostly focuses on the strategic realm. Its two main components are reinforcing the existing U.S.-led alliance system in the region and reinforcing the U.S.' own military position within the region. According to one source: ${ }^{12}$

The security and military components of the pivot have both high profile and substantive investment. In the context of an overall militarization of U.S. foreign policy, the highest-profile initiatives of the U.S. pivot to Asia lie in security and the military.

The current strategic rebalance is necessitated by the policies of the previous Bush administration. The Bush era of American foreign policy will be always marked by the global War on Terror and the reductionist simplicity of one being either with Washington or against Washington on the matter. The Bush administration pursued the War on Terror with a simple-minded determination at the expense of all other foreign policy objectives. The uncompromising attitude of the administration alienated allies, brought the U.S. military to the brink of exhaustion, required a deep financial sacrifice and in general weakened the U.S.' position as the leader of the international system. While it risks confusing correlation with causation, it cannot be dismissed as a mere coincidence that a more assertive Chinese foreign policy emerged during a period when the U.S. attention was occupied by two wars in the Middle East. The U.S.' increasingly difficult military engagement in Afghanistan and Iraq, combined with its growing reliance on Chinese creditors to finance the wars lowered the U.S. credibility as a deterrent to hostile Chinese regional policies. President Obama was elected on a platform of change to make a clear break with the Bush 
era. In the foreign policy realm this break was the reprioritization of the Asia-Pacific.

The pivot's initiative to strengthen a direct U.S. military presence in the region is substantial. The current plan is to shift the balance of US forces from a 50-50 percent distribution between the Atlantic and the Pacific to a 60-40 percent distribution favouring the Pacific. This is a clear recognition of the vital importance the Asia-Pacific region has for continued U.S. security. The U.S. desire to expand its military presence can be seen all across the region: plans to station U.S. Marines in Australia, rotating naval patrols through Singapore, reopening the naval complex at Subic Bay ${ }^{13}$, or contradictory rumours about stationing reconnaissance airplanes in Malaysia. ${ }^{14}$ Besides increasing actual military presence on the territory of allied states, the U.S. is also expanding its naval base on Guam. ${ }^{15}$ The inconvenient truth is that the U.S. cannot afford a hands-off approach in this matter: no regional state, with the possible exception of Japan, possesses military power comparable to that of China's. The direct involvement of U.S. forces is necessary to counterbalance a growing Chinese military clout.

However, besides direct military deployment, the pivot also recognizes the critical need to engage regional states and to strengthen existing alliances and build new ones if the U.S. wishes to have a sustained presence in the region. The nearest U.S. territory is Guam, the other edge of the second island chain. If the U.S. wishes to maintain a deterrent through a strong presence right in China's back yard, it needs the cooperation of regional allies. A strong relationship is also necessary as in the event of a conflict these countries would suffer the first wave of a Chinese missile campaign on virtue of offering bases and facilities to regional U.S. military forces. The pivot seeks to address this issue through increased military aid and closer defence cooperation. The success of the policy can be seen in the detractors' claim that it is creating an unrealistic expectation among regional states of U.S. assistance, thus increasing the likelihood of confrontational politics towards China. ${ }^{16}$ However, from a U.S. perspective this is not necessarily negative, as it highlights the pivot's effectiveness at reassuring regional states as well as its ability to lower the effectiveness of China's charm offensive, as long as the U.S. have the willingness to carry out its promise of protection. 
Continued access to allied bases is especially crucial, as the pivot cannot be seen as a single decisive engagement. To successfully execute it, the U.S. will need a sustained regional presence and the required supporting infrastructure. This can only be achieved if the relationship continues to be strong and stable. Getting kicked out from a regional ally, as the U.S. military was from Subic Bay in 1992, would have significant negative implications. The dispersion of U.S. troops is also important in light of China's preferred way of fighting. Reduction in regional allies would require higher concentration of troops in a smaller number of regional bases, the ultimate extreme being a full concentration on Guam. This would increase the U.S. forces vulnerability to pre-emptive missile attacks, a core component of Chinese Anti-Access/Area Denial (A2/AD) strategies.

On the operational level, the pivot is accompanied by the development of the new Air-Sea Battle (ASB) concept. Similarly to the pivot itself, the diplomatic double speaks reasserts that it is not aimed at any particular nation. However, just as there is no reason for the pivot if not to oppose China, the ASB concept focuses on breaking A2/AD strategies, a key focus of Chinese military development. Most of the ASB concept remains classified; the U.S. Department of Defense only published a short and fairly generic unclassified summary. ${ }^{17}$ The document identifies that strategies aiming to limit the effectiveness of the "U.S. and allied expeditionary warfare model of power projection and manoeuvre" 18 as the key contemporary concern for American strategic planning. The ASB proposes an aggressive and action oriented solution: to directly degrade the enemy's A2/AD infrastructure through the destruction or disruption of its Command, Control, Communications, Computers, Intelligence, Surveillance and Reconnaissance (C4ISR) capabilities, missile launchers and other weaponry, and command positions. Most of these would require a direct military strike on the Chinese mainland. The ASB urges Washington to provide the necessary resources needed for the research and development of necessary technologies and for the construction of necessary systems and platforms to acquire the needed capabilities.

Overall, the pivot offers a solution to a traditional security issue through relying on traditional U.S. strengths: bilateral security arrangements and the sheer unmatched force of the U.S. military. This article already argued that opposing the disruption of the status quo is 
a worthy goal for the U.S. But does the pivot offer an effective way to do so? The regional component of regional hegemony is the key here. A state can only achieve regional hegemony, a prerequisite to a state of security that enables it to leverage this hegemony into global influence, if it removes any significant threat to its security from its home region. Mearsheimer argues that this also means that an effective way for existing hegemons to oppose the emergence of new hegemons is to maintain a meaningful threat in their home region, namely to maintain a strong military presence that could be potentially used in a confrontation. ${ }^{19}$ The pivot aims to achieve just this: The key objective of the policy is to maintain a strong U.S. military presence in Asia, accompanied by a stable system of allied powers. This would prevent China from dominating the region, i.e. achieving regional hegemony.

Keeping China purposefully insecure to serve U.S. interests can be seen as counter-intuitive at first. However, this is only so because this view rests on the idea that the key goal of U.S. foreign policy would need to be to avoid a confrontation with China. On the contrary, the maintenance of the status quo as a goal may very well require a confrontation with China. The reasons to keep China insecure is quite straightforward: if Beijing continues to be concerned about its security in its home region, on account of a strong rival military presence, it will focus its energies on increasing its security in East Asia, as opposed to using the same assets to project power outside the region. A strong U.S. military presence in East Asia forces Beijing to focus their attention on the region, to overcome the insecurity derived from a U.S. presence, as opposed to influence, and thus potentially threaten the U.S.' interests, elsewhere. This insecurity is also useful to curtail revisionist efforts. With a strong military force stationed at striking distance from the Chinese mainland, Beijing has to be more mindful of how a certain policy direction would be viewed by the U.S., than in a situation where it achieved regional hegemony, and can feel safe in the knowledge, that no direct threat to its home territory exists.

On the operational level, the ASB concept also represents a good direction. For the past decades the PLA invested heavily into anti-access and area denial capabilities in an attempt to insulate the Chinese mainland from a potential U.S. military response if Beijing decides to pursue military action, for example against Taiwan. The ASB concept aims to strip away the perceived invulnerability 
derived from A2/AD to reassert the U.S. military's ability to threaten an adversary, and thus to effectively act as a force of deterrent. If Chinese strategic thinkers are confident that their A2/AD measures could meaningfully diminish the threat posed by the U.S. military, Beijing would be more likely to consider military action in pursuit of its interest, as the consequences would be perceived as less severe. However, the successful implementation of the ASB concept would signal that the U.S. military not only could, but would be willing to dismantle China's A2/AD defences and that this strategy would not act as an effective deterrent to U.S. military action. This would shift back the balance of forces in the favour of the U.S. and force Beijing to be more mindful of U.S. interests.

One of the key charges against this approach is that keeping China insecure and developing ways to attack the mainland is likely to trigger an armed confrontation. ${ }^{20}$ Which is of course absolutely true. But that is not the failure of the policy. The goal is to ensure the maintenance of the status quo, which offers unprecedented freedom for the U.S. to pursue its interests, and that the U.S. military can win a confrontation, not avoid it. The only way to surely avoid a confrontation is through appeasement during which the U.S. on its own initiative, slowly but surely surrenders its strategic position to a rival.

\section{THE MIDDLE EAST AND MILITARIZED COUNTER- TERRORISM}

Recent events in Sydney and Paris, as well as headlines concerning the sheer inhuman barbarity of ISIS, once again pushed the issue of terrorism and how to deal with it to the forefront. And once again, an increasing number of people consider the solution to be to carry out a military campaign against ISIS in Syria and Iraq and to vanquish them, as if they were an enemy state. The idea is not new, but it continues to be based on the fallacy that entities like ISIS can be engaged similarly as established states. Even if coalition forces would manage to recapture every stretch of land currently held by ISIS, it would not be the end of the group. The difficulty of counter-terrorism lies in the fact that terrorists can hide among the civilian population and continue to wage a campaign of violence without a form against which to direct traditional military power. If one attacks a country, he can attack the infrastructure, demolish industrial centres, and bomb 
military bases to force an enemy to subject. And while in recent years some terrorist groups established similar infrastructures, their destruction is insufficient to end their existence. The Charlie Hebdo attack was carried out by two gunmen with small arms. The Sydney siege by a lone gunman. One cannot exactly direct a Predator drone at such a targets.

Furthermore, renewed calls for the application of military power against ISIS shows how extremely short shared memory is when it comes to policy. The Bush administration has been infamous for its reliance on traditional military power to counter terrorism. And after eight years it was collectively decided that it was not a good policy direction, showed by the fact that end of term Gallup assessment shows that he ended his presidency, whose defining characteristic has been the War on Terror, with a 61 percent disapproval rating, only topped by Richard Nixon. ${ }^{21}$ One of the key promises of the Obama administration was to break from the path set by Bush. The pivot promises to achieve that. Yet, during the Obama presidency the U.S. was involved in a war in Libya, maintains an expansive drone program in both Africa and the Middle East, literally raining down hellfire, often indiscriminately, on suspected terrorists and is involved in a military campaign against ISIS. Senator John McCain went as far as to argue that the U.S. needs to be involved in the ground to counter ISIS ${ }^{22}$, and especially on the political right the idea of increasing military involvement in the Middle East once again is gaining traction, for obvious political considerations that have less to do with the best interests of the nation and more to with the best interests of the Grand Old Party (GOP). However, continued a once again expanded military involvement in the Middle East would be disastrous. In the following the question of the Middle East policy will be subjected to the same analysis as the East Asia policy and the pivot: Does it pursue an objective worth pursuing? Does it pursue it effectively?

The stated goal of continued U.S. military involvement is counter-terrorism. To paraphrase the eloquent words of George W. Bush, we have to fight them over there, so we don't need to fight them over here. One could argue, and many have argued, that the real justification for this involvement is oil, outflanking Iran or that the U.S. government is dominated by the Illuminati and lizard people living in the centre of the Earth. Regardless, the official justification for the 
Afghan war was to eliminate the Taliban terrorist state, for the Iraq war was to topple Saddam's terrorist regime trying to acquire weapons of mass destruction (WMDs) and for the current airstrikes against ISIS is to oppose the militant group. The evaluation of policy will be made on its stated objectives, not possible ulterior motives behind it.

Terrorism is the great fear of our age. The 9/11 attacks fundamentally changed our view of the world, and we are most certainly more afraid than before of extremists militants trying to take down the Western world one Walmart at a time. But, removing the hysterics, how significant is the actual threat of terrorism for the average citizen of the West? An April, 2014, assessment released by the U.S. Department of Homeland Security states that: ${ }^{23}$

Although terrorist attacks occurred in 93 different countries in 2013 , they were heavily concentrated geographically. More than half of all attacks (57\%) and fatalities (66\%), and nearly three-quarters of all injuries (73\%) occurred in three countries: Iraq, Pakistan, and Afghanistan.

A similar report from the State Department also stated that: ${ }^{24}$

Muslims continued to bear the brunt of terrorism... Muslims suffered between 82 and 97 per cent of terrorismrelated fatalities over the past five years.

To put this into practical numbers, in 2013 a total of 17,891 fatalities were attributed to terrorism. A mere 16 of them were Americans, which is roughly 0.09 percent of the victims. Within the same period, over 3000 kidnappings attributed to terrorism occurred globally. Once again, only 12 of them were Americans, or 0.4 percent. ${ }^{25}$ In case of ISIS, less than half a dozen foreigners were beheaded before meriting an air campaign. The numbers simply do not support the idea that terrorism is a strong threat to the safety of American citizens, The Atlantic going as far as to argue that "the number of U.S. citizens who died in terrorist attacks [is] overall comparable [to the] number of Americans crushed to death by their televisions or furniture each year."'26

The threat of terrorism is further reduced once one considers whom the victims have been. ISIS beheaded aid workers and 
journalists already in Syria. This is not to imply that they deserved their fate. At the same time, they were not abducted from a public space within the continental U.S. frequented by the average citizen. They willingly entered into a warzone where the extremist group operated. They are victims of opportunity due to circumstances most US citizens will never encounter.

The objective reality is that the threat of terrorism has been massively overhyped for domestic political gain. Currently the threat posed by terrorism does not warrant the effort and energy spent on it. This is not to undervalue the importance of the safety of the citizens, but to highlight that terrorism should be treated appropriately among all the threats. And at the moment high fructose corn syrup presents a significantly higher risk of death and injury to the average American than terrorism.

One can also examine recent tragedies in this light. The Sydney terror attack claimed the lives of two civilians, one of whom died as the result of the police storming the café. The Charlie Hebdo attacks initially claimed the life of 14, with added collateral casualties later on. While every loss of life is a tragedy, quantitatively the number of casualties does not support the special attention attributed to them. The only meaningful difference between these acts and regular murder is the political motive behind them, and the visceral reaction created them achieves exactly what their perpetrators were looking for. News outlets have shown a preference to dramatize the events, showing a long list of terror attacks in the West: $9 / 11$, the Madrid bombing, the 7/7 London bombings, Sydney and then Paris. Yet the overall casualties, discounting 9/11, have been relatively low. The disproportionate response to terrorism fatalities is puzzling: The Sandy Hook elementary school shooting left 20 children dead. Yet no one proposed to invade Connecticut in response, it was even insufficient to move the debate ahead on gun control and the state of the mental health system in the U.S. At the same time, the death of journalists in a warzone or a single act of terror perpetrated by enemy combatants is sufficient to prompt air strikes in a distant part of the world and to begin considering the deployment of a full scale expeditionary force.

Furthermore, even if we would argue that terrorism is the greatest threat that ever existed, is the method we use currently deal 
with it effective? From the Bush era onward, U.S. counter-terrorism strategy has been highly militarized. The response shifted from preventing potential terrorist from entering the country, or if already here, preventing them from carrying out an attack to going to their supposed home country and killing them there. Fundamentally U.S. policy tries to solve a non-traditional security threat through the application of traditional military power, a fundamental misconception of the phenomenon.

Case in point is the war in Afghanistan. The U.S. declared war on the Taliban regime for supposedly providing safe harbour to Osama bin Laden and the rest of his organization. To oppose a group, the U.S. attacked a state. Taliban Afghanistan as a state posed no threat to the U.S. as it only possessed rudimentary military power, just sufficient to maintain the oppressive fundamentalist regime. The Taliban, as a state, sought no aggression against the U.S. and were perfectly content on shooting down kites and subjugating their women in isolation. Then the U.S.-led coalition invaded. The U.S. got entangled in a difficult and expensive military campaign against an insurgency it created itself by disrupting a sovereign state. And Osama bin Laden and the Al-Qaeda simply moved over to Pakistan and other unstable states, defeating the whole purpose of the initial intervention. Terrorism as a threat was not reduced by the sacrifice of the U.S.

The same can be said about the ISIS. It seeks to establish an Islamic Caliphate, which on the rhetorical level threatens the U.S. But if one strips away the posturing, a simple picture emerges: the ISIS has little over 30,000 militants, according to intelligence estimates, which it uses to maintain an oppressive regime over a population that is largely unfriendly to this endeavour, and is surrounded by territory that is outright antagonistic to it. It barely has the manpower to sustain its current gains in the long run, let alone conquer large stretches of new land. Even if it succeeds in creating an Islamic state, it is very unlikely that its existence would have a meaningful impact on the international society, just as the decades of Taliban rule in Afghanistan had no effect on it before. Neither the existence of Taliban Afghanistan and an ISIS Caliphate as a state is a direct threat to the U.S.

Besides, fighting terrorism in this manner is probably the most foolish thing to do. It offers to the enemy to fight on his home turf, 
where he possesses most advantages and U.S. forces are open to most disadvantages, as opposed to fighting it at home where the U.S. can enjoy the benefits of its own massive surveillance network, a cooperative population and the general isolation of would be terrorists. Why would one choose to fight an adversary in the mountains of Waziristan, when the same overall result can be achieved with better border security and domestic surveillance? The best refutation of a militarized counter-terrorism strategy is its own track record. The wars in Iraq and Afghanistan did not even curtail global extremism, let alone destroy it. On the contrary, they provided justification for many would be extremists to take up the cause.

Furthermore, there is no evidence to support that terrorism can be uprooted in such a fashion to begin with. Once their visible infrastructure is destroyed, terrorists can retreat underground, blend into the civilian population, making them difficult to identify. In today's digital age, it is foolish to assume that terror cells could not be formed and operated without a physical territory controlled by the group. The Irish Republican Army's (IRA) long campaign of violence demonstrated decades ago that such activities are possible even if the territory is tightly controlled through military force. It is reasonable to assume that even if the contested territory would be liberated, ISIS militants would just retreat and continue their ideological campaign of violence through different means. It would end the suffering of the local population, but it would not solve the threat of terrorism.

One's response has to be proportionate to the threat. The current approach would require the U.S. to invade and forcefully stabilize all unstable countries in the world, and even then it would be failure. The fact that anarchist terrorism existed in Germany, among other instances of domestic terrorism, proves that even if deprived of an actual home country, extremist groups can and will form and they will plan attacks. Invading otherwise strategically irrelevant countries, like Afghanistan or Syria, is a gross overreaction.

Terrorism is best tackled by law enforcement and clandestine agencies at home, as done by all developed nations. This cannot guarantee that no terror attacks will occur ever again, as it is inevitable that something falls through the cracks. However, considering this as a failure would be equivalent to considering the police force a failure 
for failing to stop any and all pickpockets. Living with a low risk of terrorism offers a more efficient alternative to the attempt to militarily routing out terrorism, and expensively failing at it. Furthermore, terrorism should be considered within the framework of violent crimes. The visceral reaction to each act of terror, disproportionate to their actual effect on the nation as a whole, lends power to these acts. Shifting how the population thinks about terrorism could deprive it from most of its power. Violence is unavoidable, whether it is for ideological reasons, material gain or simply caused by poor mental health. The key objective is to keep it acceptably low and to ensure that it is met with appropriate force.

That said, it is easy to understand how terrorism appropriated such a central position in the national conversation. It is visceral and brutal. Blowing up civilians, throwing acid into the faces of schoolgirls, committing religious genocide and selling women into sexual slavery ignite one's righteous moral outrage. From a humanitarian perspective it is self-evident that one should be opposed to groups like ISIS. Their barbarity is the sort that keeps anyone with a shred of empathy up at night. Yet, moral outrage is a poor guide to government policy in general, and to the application of military force in particular. Gray warns us highlighting that "politics, domestic and international, is not a morality tale. ${ }^{, 27} \mathrm{He}$ further asserts that: ${ }^{28}$

It is not about doing good or being right in some ethical sense. States do not often go to war for moral reasons. Statesmen are obliged to protect the vital interests of their community, and those interests do not include the enforcement of justice, or the punishment of evil, both as culturally determined...

The reality is that the security of U.S. citizens could be better served by focusing on domestic counter-terrorism efforts and isolating unstable states, as opposed to directly invading them.

\section{THE NECESSITY OF CHOICE}

After all of this, one could still argue that, yes, East Asia is important, and that U.S. counter-terrorism strategy is not the best, but it is still better than nothing, so can't we just pursue both? The inconvenient 
reality is that no, the U.S. needs to make a strategic choice. It is simply not possible for the U.S. to pursue the pivot successfully while maintaining its current Middle East policy of military entanglement at the same time.

First of all, while the U.S. is a nation of vast resources, it is not a nation of infinite resources. Creating the strategic presence required by the pivot is not going to be cheap. The U.S. needs to maintain the military gap with China, besides maintaining its various other global military commitments, and this requires significant resources. In East Asia the U.S. needs to build a military force capable of winning a major war against the PLA in all strategic dimensions, including at sea, in the air and in the cyberspace. It also needs to maintain its edge over a rapidly modernizing PLA, which requires research and development and the acquisition of equipment. And it needs to achieve this in an age of growing fiscal restrictions and declining military spending. ${ }^{29}$ The successful execution of the pivot is ambitious on its own. At the same time, the US war in Iraq cost US\$1.7 trillion, with US\$490 billion still owed to war veterans. Associated expenses, namely what is owed to veterans, could grow to more than US\$6 trillion in the next 40 years. ${ }^{30}$ Britain's limited involvement in Afghanistan compared to the usual U.S. war efforts costs $£ 37$ billion. ${ }^{31}$ The fact is that these counter-terrorists wars are not cheap. Executing one parallel to the pivot would divert crucial funding away from it. In case of a long-term effort such as the pivot, the U.S. would need to maintain it for the rest of the existence of a strong China after all, it cannot be avoided that other contingencies arise. However, resources should not be wasted on needlessly undertaken contingencies of dubious results. The pivot is also reliant on allied states. The U.S. would need to provide significant military assistance to states like the Philippines to bring them into fighting shape, which requires further resources.

Second, as Chinese military power continues to grow, the U.S. will need to commit more and more military force to the pivot to maintain effective deterrent, until Chinese military power peeks. Getting entangled in Middle Eastern wars would divert troops away from this effort. As the insatiable need for manpower of the two previous wars grew, the U.S. military was forced to redeploy troops from other areas. In case of the pivot, this would mean that the U.S. 
needs to weaken its Asian military presence to fight these wars, which goes against the principles of the policy. Third, the two contingencies require vastly different militaries. Continued in counter-terrorist wars in the Middle East requires a ground focused expeditionary army with the capability to not only invade, but occupy a territory - a key failure of the previous wars was the lack of recognition for post-war involvement. It prioritizes mine resistant vehicles, close air support (CAS) aircraft and other similar equipment. The pivot requires a military focusing on large-scale military-against-military engagement, as opposed to counter insurgency, primarily fought at sea and in the air. It prioritizes submarines, carriers, air superiority fighters and similar equipment. The U.S. could attempt to build a force aiming to be good at both, but then both fields would suffer. The simple fact is that it needs to prioritize one over the other. And, while a naval focused military could not only offer decisive advantage on the overall strategic level, but could be reasonably effective at answering other threats on a more limited scale, a counter-insurgency focused force would face significant difficulties trying to project power into the security environment of East Asia. A war against China would require destruction, not occupation.

Fourth, the success of the pivot is dependent on the confidence of allied regional states about the U.S.' willingness to act, if push comes to shove. The policy is doomed if states perceive that in the end the U.S. would not be willing to go to the end in maintaining its regional role, i.e. in effect it is a mere paper tiger hoping that deterrence will work. Being tied up in other wars certainly does not help to reduce the fear of abandonment. Fifth, the U.S., in its action-oriented approach, allowed other states to become freeloaders within the international system with reasonable expectations that the U.S. will take care of their problems. This continuously threatens to overburden the U.S. security establishment. Remaining only in a supporting role in any conflict not directly linked to major U.S. interests would force U.S. allies to 'pick up the slack', so to speak, which in the long run would benefit the U.S. as it would create more reliable and useful allies, which in turn would allow the conservation of resources and allow a better response to crucial security threats. In the end, the U.S.' continued eagerness to get militarily involved in the Middle East is a dangerous distraction and a crucial threat to the pivot, a policy that overall offers 
far more significant benefits for the U.S. than any Middle Eastern engagement could.

\section{CONCLUSION}

In the end, it is simple: the U.S. needs to de-prioritize its role in the Middle East, at least militarily. It can continue to be engaged in the region diplomatically, but U.S. military force can and should be better utilized elsewhere. The Obama administration correctly realized that East Asia is of crucial importance for the U.S. The continued rise of China threatens, for better or worse, to inflict fundamental change on the balance of power and thus on how the U.S. pursues its interests. The U.S. has enjoyed a uniquely advantageous position since the end of the Cold War. While there is no reason to pass judgment on Beijing for attempting to mitigate the nature of the international system in a rational manner, that however should not distract from how it affects the U.S. strategic interests. For U.S. policy the question is not whether the emergence of China as a regional hegemon would be a good or bad thing in an abstract sense, but whether it would negatively impact U.S. interests. As the answer is affirmative, the U.S. is forced to oppose it, or concede its advantages.

The pivot, at least conceptually, represents a good approach. It addresses a crucial issue and it does so in a seeming effective manner. How the policy will be executed remains to be seen. However, it represents a good direction and it is based on strategically sound ideas. Despite being a good policy, the pivot continues to exist in the shadow of counter-terrorism and the Middle East. Growing U.S. preoccupation with ISIS is not an encouraging sign. The simple truth is that the number does not support the extent of the effort the U.S. spends on the issue. Militarized counter-terrorism is not only not a good objective, but not even an effective way to pursue a bad objective. Washington should shift away from the Middle East, and abandon its eagerness to fight wars in the region. This would not only eliminate a bad policy, but it would ensure that resources are conserved for actual good policies, such as the pivot. While the moral outrage over the issue, as well as the domestic political support a politician can gain from it, is easily understandable, continued subordination of policy 
to such moral outrage will have far-reaching and grave consequences for the US.

The inconvenient reality is that if the U.S. wishes to continue to enjoy the benefits of its uniquely advantageous political position, it simply has to return to basing policy on rational self-interest, as opposed to emotional outcries. And this means abandoning its current interventionist attitude towards the Middle East.

\section{NOTES}

1 The article was produced as part of my doctoral program in security and strategic studies at the University Malaya. For the duration of the program, the author's work, including this article, has been supervised by Dr. K. S. Balakrishnan and Associate Professor Dr. Jatswan Singh.

2 Robert E. Kelly, "Will Islamic State Cripple the Pivot?," The Diplomat, 13 November 2014, <http://thediplomat.com/2014/11/will-islamic-statecripple-the-pivot/>

3 Colin S. Gray, Fighting Talk: 40 Maxims on War, Peace and Strategy, London: Praeger, 2007, p. 134.

4 John J. Mearsheimer, The Tragedy of Great Power Politics (Updated Ed.), New York, London: W. W. Norton \& Co., 2014.

5 Ibid.

6 The World Bank, "Gross Domestic Product 2013," < worldbank.org/data/download/GDP.pdf>

7 Stockholm International Peace Research Institute (SIPRI), "Sipri Military Expenditure Database," <http://www.sipri.org/research/armaments/milex/ milex_database $>$

8 The World Bank, "Gross Domestic Product 2013."

9 SIPRI, "Sipri Military Expenditure Database."

10 Ibid.

11 The World Bank, "GDP Growth (Annual \%)," < http://data.worldbank. org/indicator/NY.GDP.MKTP.KD.ZG>

12 Wei Ling, "Rebalancing or De-Balancing: U.S. Pivot and East Asian Order," American Foreign Policy Interests, Vol. 35, No. 3, 2013, p. 150. 13 Ibid.

14 "U.S. Says Malaysia Offers to Host Spy Planes That Irk China," Reuters, 12 September 2014, <http://www.reuters.com/article/2014/09/12/ us-malaysia-usa-spyplanes-idUSKBN0H72CN20140912> 
15 Praveen Swami, "Us to Build £8bn Super Base on Pacific Island of Guam," The Telegraph, 25 October 2010, <http://www.telegraph.co.uk/ news/worldnews/australiaandthepacific/guam/8085749/US-to-build-8bnsuper-base-on-Pacific-island-of-Guam.html>

16 Ling, "Rebalancing or De-Balancing."

17 Air-Sea Battle Office, "Air-Sea Battle: Service Collaboration to Address Anti-Access \& Area Denial Challenges," Washington DC: Department of Defence, 2013.

18 Ibid., p. 2.

19 Mearsheimer, The Tragedy of Great Power Politics.

20 Jeffrey E. Kline and Wayne P. Hughes Jr, "Between Peace and the AirSea Battle," Naval War College Review, Vol. 65, No. 4, 2012.

21 Lydia Saad, "Bush Presidency Closes with 34\% Approval, 61\% Disapproval," Gallup, 14 January 2009, <http://www.gallup.com/ poll/113770/bush-presidency-closes-34-approval-61-disapproval.aspx>

22 Rory Carroll, "Mccain Urges Ground Troops to Defeat Isis: 'They're Winning, and We're Not'," The Guardian, 12 October 2014, <http://www. theguardian.com/world/2014/oct/12/mccain-isis-syria-iraq-strategy>

23 National Consortium for the Study of Terrorism and Responses to Terrorism, "Annex of Statistical Information: Country Reports on Terrorism," Washington DC: Department of Homeland Security, 2014.

24 Office of the Coordinator for Counterterrorism, "National Counterterrorism Center: Annex of Statistical Information," <http://www.state.gov/j/ct/rls/ crt/2011/195555.htm>

25 Spencer Ackerman, "Global Terrorism Rose 43\% in 2013 Despite AlQaida Splintering, US Reports," The Guardian, 30 April 2014, <http://www. theguardian.com/world/2014/apr/30/global-terrorism-rose-despite-al-qaidasplintering>

26 Micah Zenko, "Americans Are as Likely to Be Killed by Their Own Furniture as by Terrorism," The Atlantic, 6 June 2012, <http://www. theatlantic.com/international/archive/2012/06/americans-are-as-likely-tobe-killed-by-their-own-furniture-as-by-terrorism/258156/>

27 Gray, Fighting Talk, p. 134.

28 Ibid., pp. 134-35.

29 Nick Simeone, "Hagel Outlines Budget Reducing Troop Strength, Force Structure," U.S. Department of Defence, <http://www.defense.gov/news/ newsarticle.aspx?id=121703> 
30 Daniel Trotta, "Iraq War Costs U.S. More Than \$2 Trillion: Study," Reuters, 14 March 2013, <http://www.reuters.com/article/2013/03/14/usiraq-war-anniversary-idUSBRE92D0PG20130314>

31 Richard Norton-Taylor, "Afghanistan War Has Cost Britain More Than $£ 37$ bn, New Book Claims," The Guardian, 30 May 2013, <http://www. theguardian.com/world/2013/may/30/afghanistan-war-cost-britain-37bnbook> 